\title{
BENEFIT COST RATIO (BCR) ANALYSIS OF THE ROAD RECONSTRUCTION USING HARDENED SHOULDER PROGRAM IN EAST JAVA PROVINCE
}

\author{
Ahmad Faathir Wicaksono ${ }^{1}$, Ratna Handayani ${ }^{2}$ \\ ${ }^{1,2}$ Road and Bridge Engineer, East Java Province Road Agency, Surabaya, Indonesia \\ E-mail: faathirahmad@gmail.com
}

\begin{abstract}
The main program of East Java Province Government on the road sector is the capacity improvement through road reconstruction using hardened shoulder project in the strategic corridor of the road province to accelerate the goods and people transport supporting the public economic welfare. The benefit cost ratio analysis is carried out to evaluate the direct benefit obtained by the road users. The research is conducted on the five main roads which represent the urban and inter-urban area by comparing the two conditions, the base alternative (do nothing) and alternative (do something) to obtain the benefit influenced by the project. The Research shows that the first year benefit gives the Vehicle Operating Cost (VOC) saving by 4,86\% and The Travel Time saving by 15,57\%. The Benefit evaluation along 10 Years program is known from five roads which was studied only three had qualified to fulfill the feasibility criteria, $B / C>1, N P V>1$ dan Nilai IRR $>r$ (discount rate $12 \%$ ) which was ranked based on the NPV/Capital value respectively Bts. Kab. Sumenep - Pantai Lumbang road by 5.425, Jajag - Simpang Lima Petahunan - Pasanggaran road by 1.429 and Kencong - Kasian road by 0.591 .
\end{abstract}

Keywords: Benefit Cost Ratio; NPV; IRR; Vehicle Operating Cost (VOC); Travel Time

\section{Introduction}

The development of road infrastructure is the East Java Province program backbone to improve the zone inter-connectivity which can leverage the economic and traffic of people and goods. Inline with the East Java Province priority program, the road construction in the industrial corridor, trading and tourist destination are needed to strengthen the traffic which can be expected to accelerate the benefit to the road users especially in the road province. The reconstruction with the hardened shoulder were started in the 2017 on the main roads both in the urban and inter-urban in order to improve the road capacity to decrease the road density as well as to shorten the travel time which can saving the vehicle operating cost (VOC). The analysis of the benefit cost ratio (BCR) is needed to evaluate the benefit during the investment life knowing whether the Government program gives the significant benefit and result as well as the important material to evaluate the strategic investment value on the next future Government programs.

The research of Benefit Cost Ratio is widely used to appraised a lot of project in Indonesia, the relationship of speed and vehicle operating cost (VOC) in Central Java Province road had been conducted using the PCI equation resulting on saving value between outer road and existing road [1]. The PCI equation is also used to calculate the vehicle operating cost (VOC) on Aceh Province to evaluate the flyover project where NPV, BCR and IRR fulfilled the feasibility requirement [2].The usage of BCR analysis not only used on the urban and interurban road appraisal but also on the suburban road which had been studied on the construction of The Lombok Timur suburban connecting road resulting on economical aspect fo feasibility of the road project [3]. In South 
Minahasa District, the benefit cost analysis is used to appraise the contruction of outer ring road using the economic parameter, NPV, IRR and BCR value[4]. The benefit cost ratio analysis is conducted on the 5 (five) road province which is the strategis provincial strategis project in the 2019 which represent the urban and inter-urban with the variation of average annual daily traffic volumes which is Babat - Bts. Kab. Jombang road, Bts. Kab. Sumenep - Pantai Lumbang, Bts. Kab. Mojokerto - Ploso, Kencong - Kasian and Jajag - Simpang Lima Petahunan - Pasanggaran. The ultimate purpose of the research as follows:

1. Evaluating the economic benefit of the reconstruction with hardened road shoulder in first year analysis.

2. Evaluating the economic benefit of the reconstruction with hardened road shoulder in the 10 Years investment life.

The benefit of the reconstruction with hardened road shoulder is known by comparing the 2 (two) scnearios which is the Base Alternative (Do Nothing) and Alternative (Do Something) along the 10 Years investment life. The calculation of the vehicle operating cost (VOC) is conducted for the private car users and neglected the other modes of transportation such as truck and buses.

\section{Material and Methods}

\subsection{Benefit Cost Ratio (BCR)}

Benefit Cost Ratio Analysis (BCR) is used to measure the economic impact resulting from the investment by comparing the cost of construction and the benefit value come out of the investment spent which is the difference between 2 (two) alternatives, before and after analysis of the reconstruction with hardened road shoulder program [5].

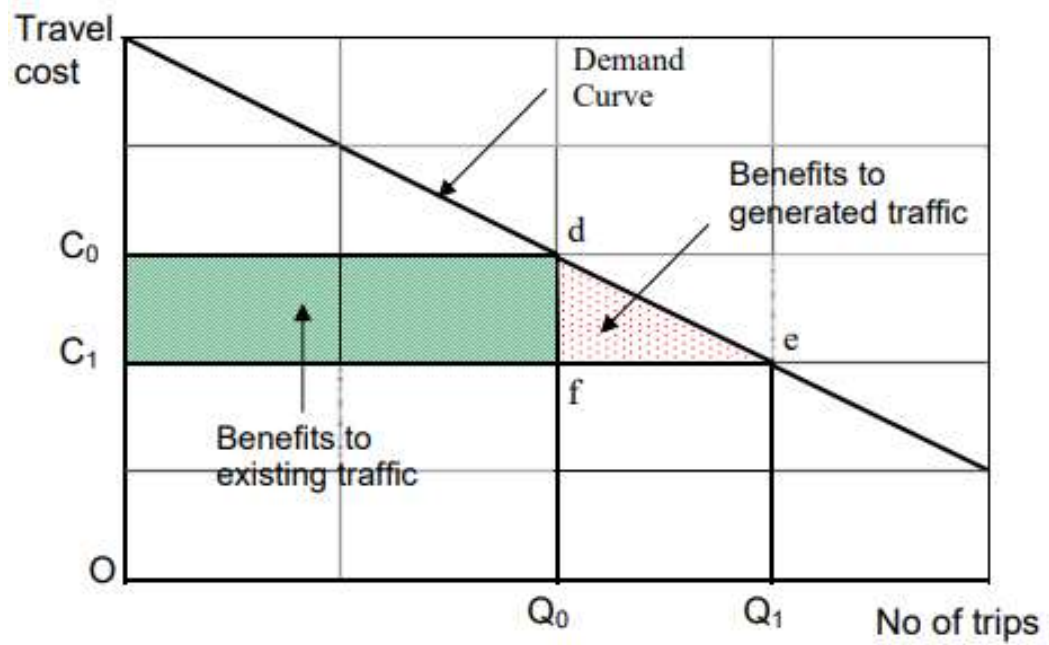

Figure 1. Road users benefit caused by the infrastructure development (UOB, 2013)

From the figure1 above known that the $\mathrm{C}_{0}$ is the vehicle operating cost (VOC) which is allocated before the implementation of reconstruction with hardened road shoulder program whilst $\mathrm{C}_{1}$ is the vehicle operating cost (VOC) which is allocated after the implementation of reconstruction with hardened road shoulder program. The difference of the cost between $\mathrm{C}_{0}$ and $\mathrm{C}_{1}$ gives the benefit for the existing and generated traffic caused by the infrastructure development.

The benefit cost ratio analysis (BCR) is conducted by fulfilling the certain parameters [6]as follows: 
- $\quad$ Time frame

- Years of construction

- First year of benefit

- Final year of analysis/year of remaining capital value (RCV)

The illustration about the benefit cost ratio analysis (BCR) is shown below:

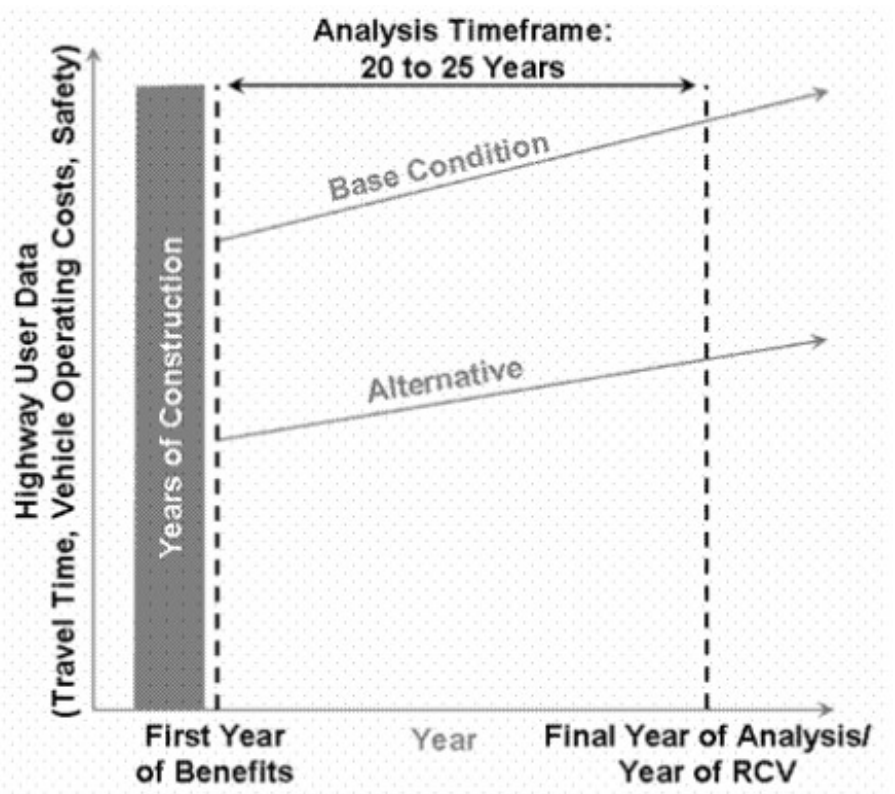

Figure 2. Time dependent in a Benefit Cost Ratio analysis (MnDOT, 2020)

Other than the Benefit Cost Ratio (BCR) value, the economic appraisal of the infrastructure project can be measured using the criterias as follow:

1. Net Present Value (NPV)

NPV describe the benefit and net value (discounted value) along the investment life with the certain discount rate. The formula of NPV is:

$$
\begin{aligned}
& N P V=B_{0}-C_{0}+\frac{B_{1}-C_{1}}{(1+r)}+\frac{B_{2}-C_{2}}{(1+r)^{2}}+\cdots+\frac{B_{1}-C_{1}}{(1+r)^{t}}+\cdots+\frac{B_{n}-C_{n}}{(1+r)^{n}} \\
& N P V=\sum_{t=0}^{n} \frac{B_{t}-C_{t}}{(1+r)^{t}}
\end{aligned}
$$

Where:

$\mathrm{B}=$ Benefit in year $-\mathrm{t}$

$\mathrm{C}=$ Cost year $-\mathrm{t}$

$\mathrm{r}=$ discount rate

$\mathrm{t}=$ horizon year

2. Internal Rate of Return (IRR)

IRR the discount rate at which the benefits and costs are needed to be discounted so that the NPV of the project becomes zero, NPV $=0$, IRR is used to appraise whether the project feasible or not in the investment scheme, the formula of IRR:

$$
B_{0}-C_{0}+\frac{B_{1}-C_{1}}{(1+I R R)}+\frac{B_{2}-C_{2}}{(1+I R R)^{2}}+\cdots+\frac{B_{1}-C_{1}}{(1+I R R)^{t}}+\cdots+\frac{B_{n}-C_{n}}{(1+I R R)^{n}}=0
$$


The project can be accepted if it is fullfiling the criterias as follows [5]:

- NPV $>0$

- $\quad$ IRR $>r$, using the discount rate $12 \%$

- $\mathrm{B} / \mathrm{C}>1$

\subsection{Vehicle Operating Cost (VOC)}

The vehicle operating cost (VOC) is the cost spent by the road user which including some of the components which is the fuel consumption, oil engine consumption, tyre usage, spare part and maintenance, depreciation and insurance. In the VOC analysis, the fuel consumption is the dominant component of the VOC. Some of the model of the vehicle operating cost had been, started from the simple equation based on the mean speed to the sophisticated equation based on the time frame, the deceleration, acceleration and engine start-stop. The vehicle operating cost (VOC) is calculated using the equation which is developed by the Pasific Consultant Indonesia (PCI) for vehicle type I (car) for non-toll road [7] as follows:

Fuel Consumption

$$
Y=0.04378 \times S^{2}-4.94078 \times S+207.0484
$$

Where

$\mathrm{Y}=$ Fuel Consumption (Litre/1000 Km)

$\mathrm{S}=$ Speed $(\mathrm{Km} /$ Hour $)$

Oil Engine Consumption

$$
Y=0.00029 \times S^{2}-0.03134 \times S+1.69613
$$

Where

$\mathrm{Y}=$ Oil Engine Consumption (Litre/1000 Km)

$\mathrm{S}=$ Speed $(\mathrm{Km} / \mathrm{Hour})$

Tyre Usage Consumption

$$
Y=0.0008848 \times S-0.0045333
$$

Where

$\mathrm{Y}=$ Tyre Usage Consumption $(/ 1000 \mathrm{Km})$

$\mathrm{S}=$ Speed $(\mathrm{Km} /$ Hour $)$

Spare Part

$$
Y=0.0000064 \times S+0.0005567
$$

Where

$\mathrm{Y}=$ Spare part times the number of the depreciate price vehicle $(/ 1000 \mathrm{Km})$

$\mathrm{S}=$ Speed $(\mathrm{Km} /$ Hour $)$

Depreciation

$$
Y=1 /(2,5 \times S+100)
$$

$\mathrm{Y}=1 /(2,5 \mathrm{~S}+100)$

Where

$\mathrm{Y}=$ Depreciation time of half of the depreciate price vehicle $(/ 1000 \mathrm{Km})$

$\mathrm{S}=$ Speed $(\mathrm{Km} /$ Hour $)$ 


\subsection{Speed}

The speed value which was used on this research is the free flow speed derived from free flow speed, Adjustment Factor for road width, side friction and road class and function [8] showed on the equation below:

$\mathrm{FV}=\left(\mathrm{FV}_{0}+\mathrm{FV}_{\mathrm{W}}\right) \times \mathrm{FFV}_{\mathrm{SF}} \times \mathrm{FFV}_{\mathrm{RC}}$

Where :

$\mathrm{FV} \quad=$ Free flow speed for light vehicle $(\mathrm{km} / \mathrm{jam})$

$\mathrm{FV}_{0} \quad=$ Free flow speed base for light vehicle $(\mathrm{km} / \mathrm{jam})$

$\mathrm{FV}_{\mathrm{W}} \quad=$ Adjustment Factor for road widht $(\mathrm{km} / \mathrm{jam})$

$\mathrm{FFV}_{\mathrm{SF}}=$ Adjustment Factor for side friction

$\mathrm{FFV}_{\mathrm{RC}}=$ Adjustment Factor for road class and function

Table 1. Free flow speed base for inter-urban road $\left(\mathrm{FV}_{0}\right)$ for light vehicle

\begin{tabular}{|c|c|c|c|c|c|}
\hline \multirow{2}{*}{$\begin{array}{l}\text { Road Type/ } \\
\text { Aligment Type/ } \\
\text { Sight Distance Class } \\
\text { (SDC) }\end{array}$} & \multicolumn{5}{|c|}{ Free flow speed base (km/hour) } \\
\hline & $\begin{array}{l}\text { Light } \\
\text { Vehicle } \\
\text { (LV) }\end{array}$ & $\begin{array}{c}\text { Medium Heavy } \\
\text { Vehicle } \\
\text { (MHV) }\end{array}$ & $\begin{array}{c}\text { Large } \\
\text { Bus } \\
\text { (LB) }\end{array}$ & $\begin{array}{c}\text { Large } \\
\text { Truck } \\
\text { (LT }\end{array}$ & $\begin{array}{l}\text { Motor } \\
\text { Cycle } \\
\text { (MC }\end{array}$ \\
\hline \multirow{4}{*}{$\begin{array}{l}\text { Six-divided lane } \\
\text { - Level } \\
\text { - Rolling } \\
\text { - Mountainous }\end{array}$} & & & & & \\
\hline & 83 & 67 & 86 & 64 & 64 \\
\hline & 71 & 56 & 68 & 52 & 58 \\
\hline & 62 & 45 & 55 & 40 & 55 \\
\hline \multicolumn{6}{|l|}{ Four-divided lane } \\
\hline - Level & 78 & 65 & 81 & 62 & 64 \\
\hline - Rolling & 68 & 55 & 66 & 51 & 58 \\
\hline - Mountainous & 60 & 44 & 53 & 39 & 55 \\
\hline \multicolumn{6}{|l|}{ Four-undivided lane } \\
\hline - Level & 74 & 63 & 78 & 60 & 60 \\
\hline - Rolling & 66 & 54 & 65 & 50 & 56 \\
\hline - Mountainous & 58 & 43 & 52 & 39 & 53 \\
\hline \multicolumn{6}{|l|}{ Two-undivided lane } \\
\hline - Level SDC A & 68 & 60 & 73 & 58 & 55 \\
\hline - Level SDC B & 65 & 57 & 69 & 55 & 54 \\
\hline - Level SDC C & 61 & 54 & 63 & 52 & 53 \\
\hline - Rolling & 61 & 52 & 62 & 49 & 53 \\
\hline - Mountainous & 55 & 42 & 50 & 38 & 51 \\
\hline
\end{tabular}

Source: MKJI, 1997

Table 2. Adjustment Factor for road widht $\left(\mathrm{FV}_{\mathrm{W}}\right)$ for light vehicle

\begin{tabular}{|c|c|c|c|c|}
\hline \multirow[b]{2}{*}{ Road Type } & \multirow[b]{2}{*}{$\begin{array}{l}\text { Effective Road } \\
\text { Width (Wc) } \\
\text { (m) }\end{array}$} & \multicolumn{3}{|c|}{$\mathrm{FV}_{\mathrm{W}}(\mathrm{km} /$ hour $)$} \\
\hline & & Level : $\mathrm{SDC}=\mathrm{A}, \mathrm{B}$ & $\begin{array}{l}\text {-Rolling: SDC A, B, C } \\
\text { - Level : } \mathrm{SDC}=\mathrm{C}\end{array}$ & Mountainous \\
\hline $\begin{array}{l}\text { Four-divided } \\
\text { lane } \\
\text { And } \\
\text { Six-divided } \\
\text { lane }\end{array}$ & 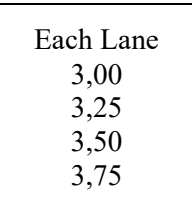 & $\begin{array}{c}-3 \\
-1 \\
0 \\
2\end{array}$ & $\begin{array}{c}-3 \\
-1 \\
0 \\
2\end{array}$ & $\begin{array}{c}-2 \\
-1 \\
0 \\
2\end{array}$ \\
\hline $\begin{array}{l}\text { Four- } \\
\text { undivided lane }\end{array}$ & 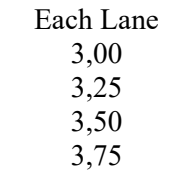 & $\begin{array}{c}-3 \\
-1 \\
0 \\
2\end{array}$ & $\begin{array}{c}-2 \\
-1 \\
0 \\
2\end{array}$ & $\begin{array}{c}-1 \\
-1 \\
0 \\
2\end{array}$ \\
\hline
\end{tabular}




\begin{tabular}{|c|c|c|c|c|}
\hline \multirow[b]{2}{*}{ Road Type } & \multirow[b]{2}{*}{$\begin{array}{l}\text { Effective Road } \\
\text { Width (Wc) } \\
\text { (m) }\end{array}$} & \multicolumn{3}{|c|}{$\mathrm{FV}_{\mathrm{W}}(\mathrm{km} /$ hour $)$} \\
\hline & & Level : $\mathrm{SDC}=\mathrm{A}, \mathrm{B}$ & $\begin{array}{l}\text {-Rolling: SDC A, B, C } \\
\text { - Level : SDC }=\mathrm{C}\end{array}$ & Mountainous \\
\hline $\begin{array}{l}\text { Two- } \\
\text { undivided lane }\end{array}$ & $\begin{array}{c}\text { Total } \\
5 \\
6 \\
7 \\
8 \\
9 \\
10 \\
11\end{array}$ & $\begin{array}{c}-11 \\
-3 \\
0 \\
1 \\
2 \\
3 \\
3\end{array}$ & $\begin{array}{l}-9 \\
-2 \\
0 \\
1 \\
2 \\
3 \\
3\end{array}$ & $\begin{array}{c}-7 \\
-1 \\
0 \\
0 \\
1 \\
2 \\
2\end{array}$ \\
\hline
\end{tabular}

Source: MKJI, 1997

Table 3. Adjustment Factor for side friction $\left(\mathrm{FFV}_{\mathrm{SF}}\right)$ for light vehicle

\begin{tabular}{|c|c|c|c|c|c|}
\hline \multirow[b]{3}{*}{ Road Type } & \multirow[b]{3}{*}{$\begin{array}{l}\text { Side Friction } \\
\text { Class (SFC) }\end{array}$} & \multicolumn{4}{|c|}{ Adjustment Factor for side friction (FFVSF) } \\
\hline & & \multicolumn{4}{|c|}{ Effective Shoulder Width Ws (m) } \\
\hline & & $\leq 0,5 \mathrm{~m}$ & $1,0 \mathrm{~m}$ & $1,5 \mathrm{~m}$ & $\geq 2 \mathrm{~m}$ \\
\hline $\begin{array}{l}\text { Four-divided lane } \\
4 / 2 \mathrm{D}\end{array}$ & $\begin{array}{l}\text { Very low } \\
\text { Low } \\
\text { Medium } \\
\text { High } \\
\text { Very High }\end{array}$ & $\begin{array}{l}1,00 \\
0,98 \\
0,95 \\
0,91 \\
0,86\end{array}$ & $\begin{array}{l}1,00 \\
0,98 \\
0,95 \\
0,92 \\
0,87\end{array}$ & $\begin{array}{l}1,00 \\
0,98 \\
0,96 \\
0,93 \\
0,89\end{array}$ & $\begin{array}{l}1,00 \\
0,99 \\
0,98 \\
0,97 \\
0,96\end{array}$ \\
\hline $\begin{array}{l}\text { Four-undivided } \\
\text { lane } \\
4 / 2 \mathrm{D}\end{array}$ & $\begin{array}{l}\text { Very low } \\
\text { Low } \\
\text { Medium } \\
\text { High } \\
\text { Very High }\end{array}$ & $\begin{array}{l}1,00 \\
0,96 \\
0,92 \\
0,88 \\
0,81\end{array}$ & $\begin{array}{l}1,00 \\
0,97 \\
0,94 \\
0,89 \\
0,83\end{array}$ & $\begin{array}{l}1,00 \\
0,97 \\
0,95 \\
0,90 \\
0,85\end{array}$ & $\begin{array}{l}1,00 \\
0,98 \\
0,97 \\
0,96 \\
0,95\end{array}$ \\
\hline $\begin{array}{l}\text { Two-undivided } \\
\text { lane }\end{array}$ & $\begin{array}{l}\text { Very low } \\
\text { Low } \\
\text { Medium } \\
\text { High } \\
\text { Very High }\end{array}$ & $\begin{array}{l}1,00 \\
0,96 \\
0,91 \\
0,85 \\
0,76\end{array}$ & $\begin{array}{l}1,00 \\
0,97 \\
0,92 \\
0,87 \\
0,79\end{array}$ & $\begin{array}{l}1,00 \\
0,97 \\
0,93 \\
0,88 \\
0,82\end{array}$ & $\begin{array}{l}1,00 \\
0,98 \\
0,97 \\
0,95 \\
0,93\end{array}$ \\
\hline
\end{tabular}

Source: MKJI, 1997 
Table 4. Adjustment Factor for road class and function $\left(\mathrm{FFV}_{\mathrm{RC}}\right)$ for light vehicle

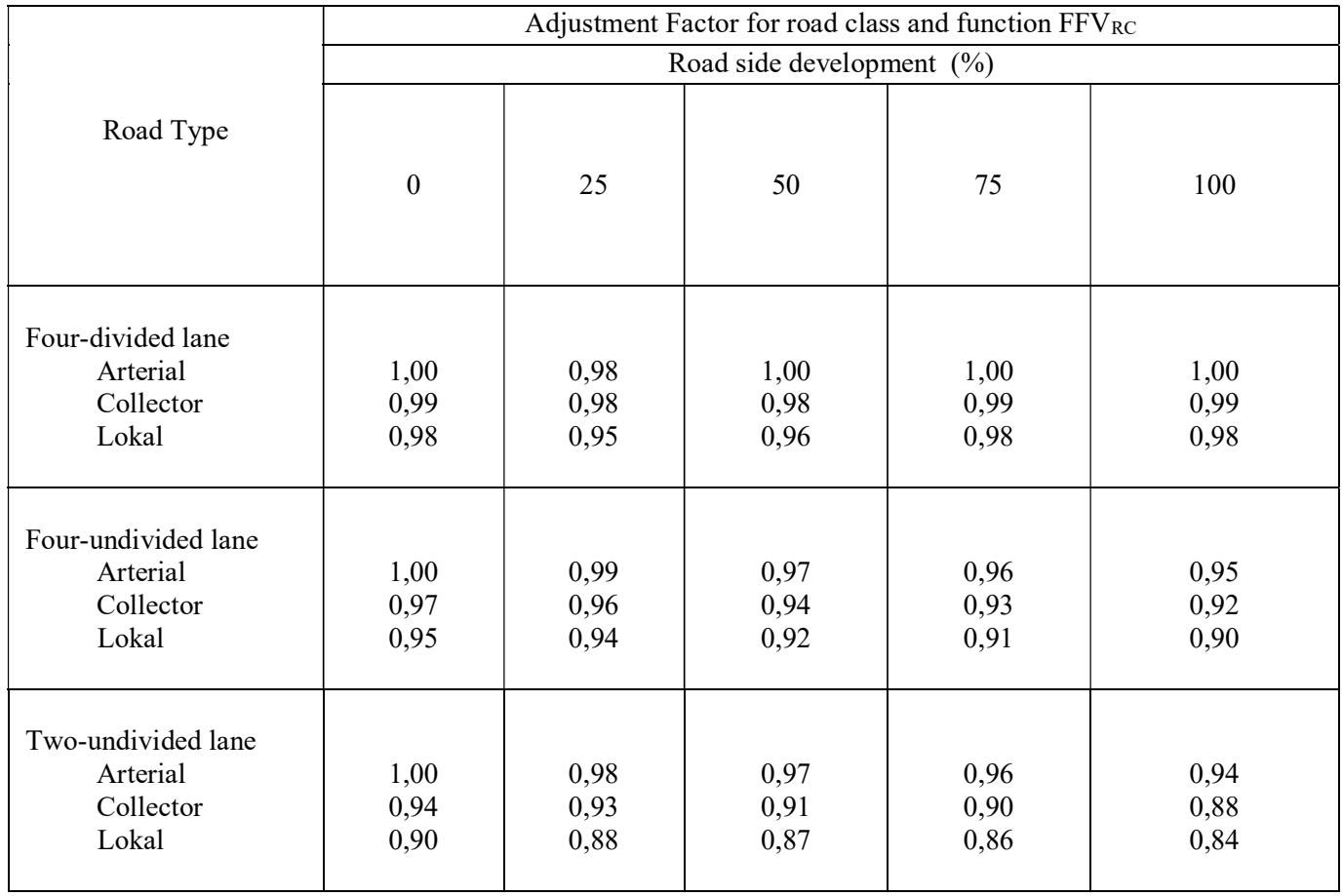

Source: MKJI, 1997 below:

Whilst the relationship between the speed and degree of saturation is shown in the graphic chart

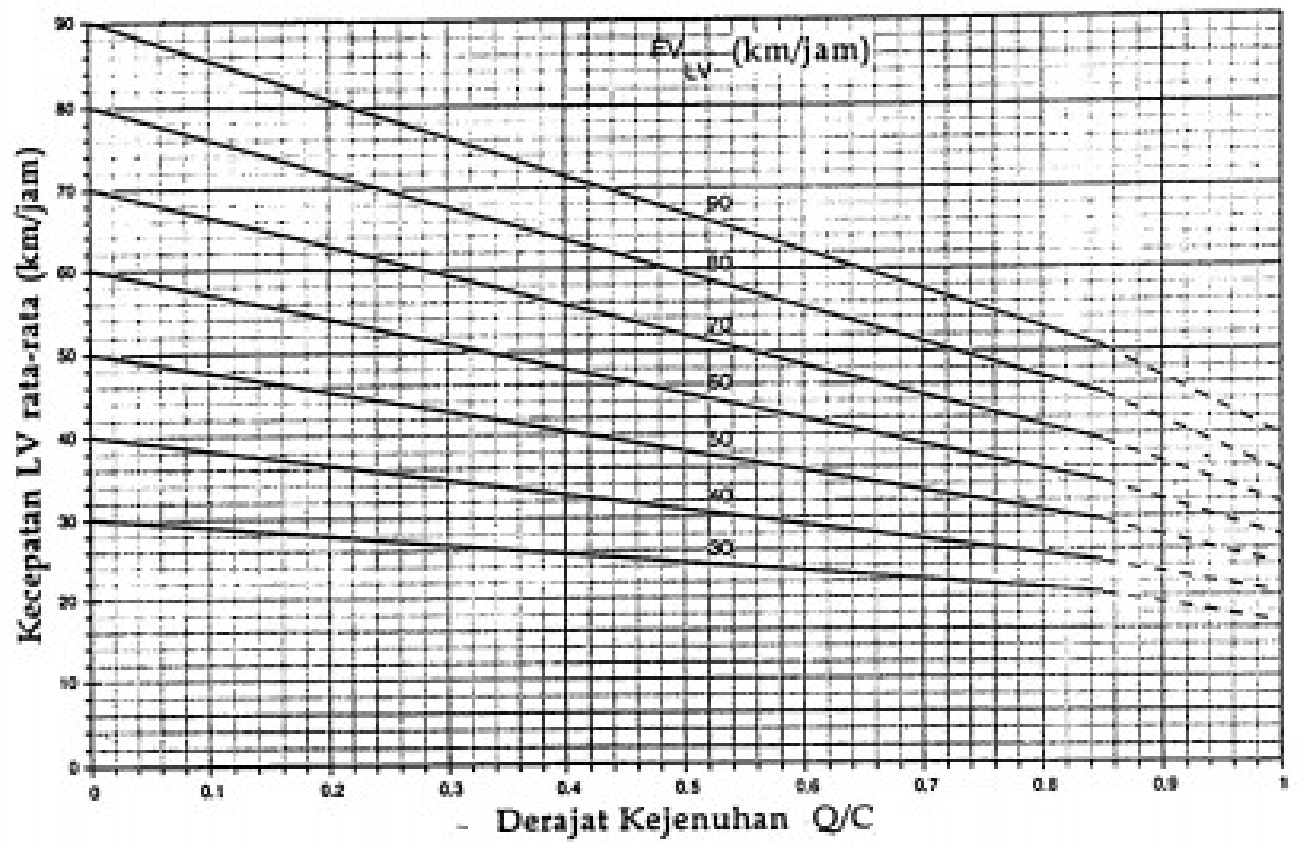

Figure 3. Speed and degree of saturation (DS) relationship for 2/2 UD road (MKJI, 1997) 


\subsection{Travel Time}

Travel time value is formulated for the workers which counted as the work productive time loss when the worker on the road which gives the benefit for the company equal with the wages accepted, while for the travel involving the non-worker the travel time is counted as the maximal satisfaction value for someone to get on the vacation or enjoying the tourism destination with the willingness to pay in order to make their travel faster and efficient [5]. In Indonesia, the research about the travel time value had been conducted by the Ministry of Transportation using Mode Gwice Approach method resulting as follows: travel time saving value for private car is Rp. 24.507/hour/person, motorcycle Rp. 14.657/hour/person and public transportation vehicle Rp. 9.320/hour/person [9]. The travel time saving is also studied for Aceh Province using income approach method where the travel time saving for light vehicle (LV) between Rp. 24.018,11 to Rp. 35.346,74/hour/person[10]. This research is using the travel time saving for private car on the benefit analysis affecting by the road reconstruction using hardened shoulder project.

\subsection{Research Method}

The research is conducted by the end of 2020 using the Annual Average Daily Traffic (AADT) of the 2018 data which will be forecasted along the 10 Years investment life, while the project will be evaluated base on the cost of construction on the 2019 for the 5 (five) road which represent the urban and inter-urban condition. The analysis is solved by comparing 2 (two) different conditions which is base alternative (do nothing) and alternative (do something) to get the benefit value from the effect of the reconstruction with hardened road shoulder project. The general description of the location studied is shown on the table below:

Table 5. The general description of location studied

\begin{tabular}{|l|c|c|c|}
\hline \multicolumn{1}{|c|}{ Road Project } & $\begin{array}{c}\text { Project Capital } \\
\text { Cost } \\
(\mathrm{Rp})\end{array}$ & $\begin{array}{c}\text { Length } \\
(\mathrm{Km})\end{array}$ & $\begin{array}{c}\text { DS } \\
(2018)\end{array}$ \\
\hline Kencong - Kasian & 7.303 .112 .631 & 1 & 0,972 \\
\hline Babat - Bts. Kab. Jombang & 7.854 .589 .000 & 1,5 & 0,602 \\
\hline Bts. Kab. Sumenep - Pantai Lumbang & 8.833 .599 .775 & 2 & 0,944 \\
\hline Jajag - Simpang Lima Petahunan - Pasanggaran & 9.274 .302 .565 & 2 & 0,709 \\
\hline Bts. Kab. Mojokerto - Ploso & 10.348 .000 .000 & 2,3 & 0,464 \\
\hline
\end{tabular}

Source: East Java Road Province, 2019

The reconstruction with hardened road shoulder project is intended to improve the road capacity by adding the road lane from $6-6,5 \mathrm{~m}$ to the road province standard which is $7 \mathrm{~m}$ with the asphalt thickness $10 \mathrm{~cm}$ and the shoulder width variated between 1-1,5 $\mathrm{m}$ adjusting the available area using the concrete material $\mathrm{fc}-20$ width $30 \mathrm{~cm}$ and base aggregate $\mathrm{B}$ width $20 \mathrm{~cm}$, the implementation of the project is finished in the 2019 involving the local contractor both low and middle class scale. The research is conducted to show the benefit of this project based the economic performance to ensure the road investment had been fulfilling the right target giving the added value for economic improvement by saving the travel time value and vehicle operating cost (VOC). The flow chart of the research can be shown below. 


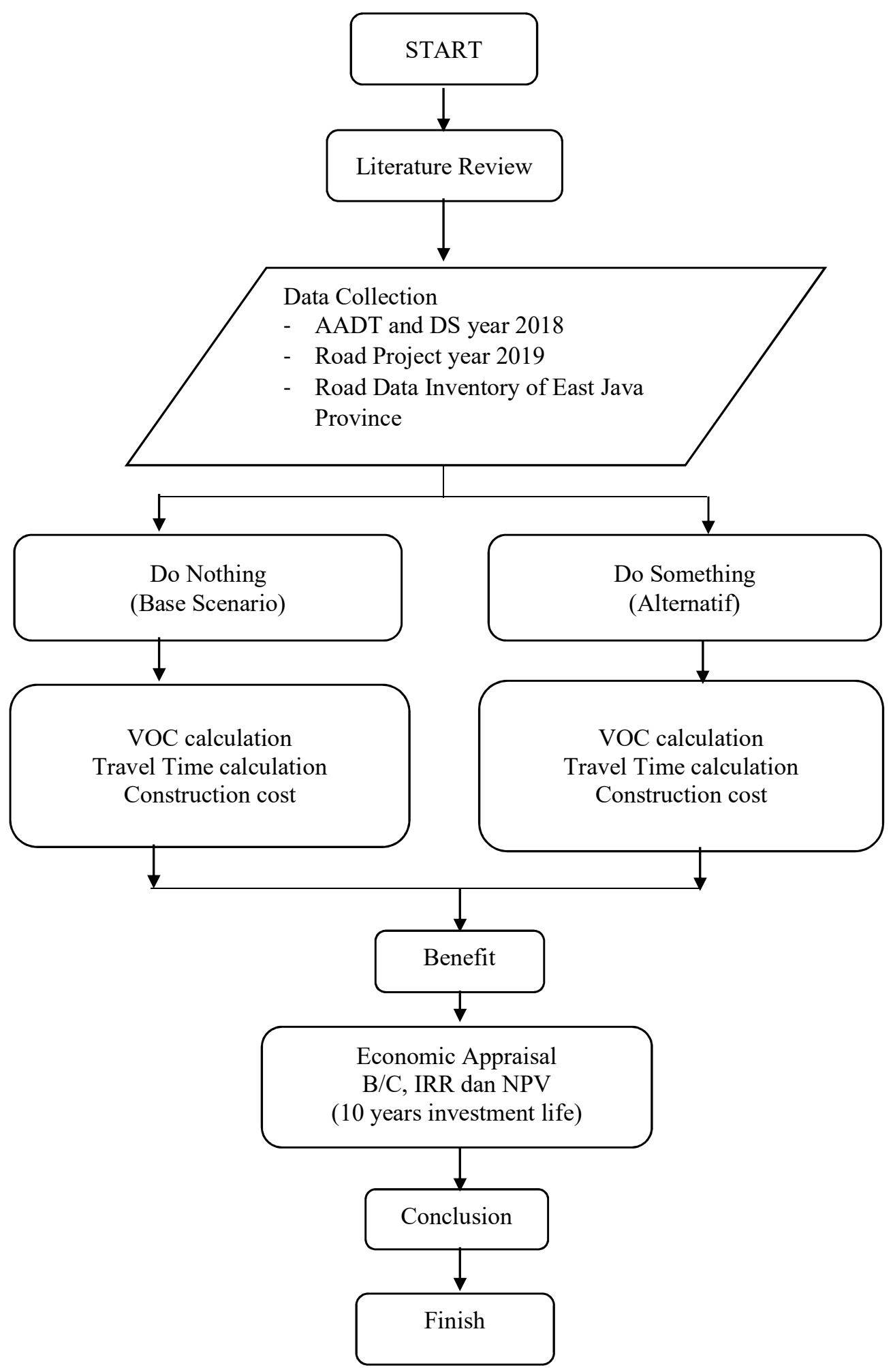

Figure 4. Flow Chart Research 


\section{Result and Discussion}

The vehicle operating cost (VOC) and travel time value are the function of speed, the speed is derivated from the degree of saturation value along the 10 years by forecasting the degree of saturation of year 2018. This table shows the degree of saturation of the five roads which had been analysed for 10 years.

Table 6. Calculation of The Forecasting Degree of Saturation value each year

\begin{tabular}{|c|c|c|c|c|c|}
\hline \multirow{2}{*}{ Road } & \multirow{2}{*}{ Condition } & \multicolumn{4}{|c|}{ Degree of Saturation/Year } \\
\hline & & 2018 & 2019 & 2024 & 2029 \\
\hline \multirow[t]{2}{*}{ fKencong - Kasian } & Do Nothing & 1,018 & 1,038 & 1,120 & 1,221 \\
\hline & Do Something ( & 1,018 & 0,926 & 1,019 & 1,111 \\
\hline \multirow{2}{*}{$\begin{array}{lll}\text { Babat - } & \text { Bts. } & \text { Kab. } \\
\text { Jombang } & & \end{array}$} & Do Nothing & 0,602 & 0,614 & 0,662 & 0,722 \\
\hline & Do Something (Alternative) & 0,602 & 0,596 & 0,655 & 0,715 \\
\hline \multirow{2}{*}{$\begin{array}{l}\text { Bts. Kab. Sumenep - } \\
\text { Pantai Lumbang }\end{array}$} & Do Nothing & 0,944 & 0,963 & 1,039 & 1,133 \\
\hline & Do Something (Alternative) & 0,944 & 0,754 & 0,829 & 0,904 \\
\hline \multirow{2}{*}{$\begin{array}{l}\text { Jajag - Simpang Lima } \\
\text { Petahunan - Pasanggaran }\end{array}$} & Do Nothing & 0,709 & 0,723 & 0,779 & 0,850 \\
\hline & Do Something (Alternative) & 0,709 & 0,489 & 0,538 & 0,587 \\
\hline \multirow{2}{*}{$\begin{array}{l}\text { Bts. Kab. Mojokerto - } \\
\text { Ploso }\end{array}$} & Do Nothing & 0,464 & 0,473 & 0,510 & 0,557 \\
\hline & Do Something (Alternative) & 0,464 & 0,314 & 0,345 & 0,376 \\
\hline
\end{tabular}

Source: East Java Road Province, 2019

The degree of saturation value which can be derivated to speed is shown below

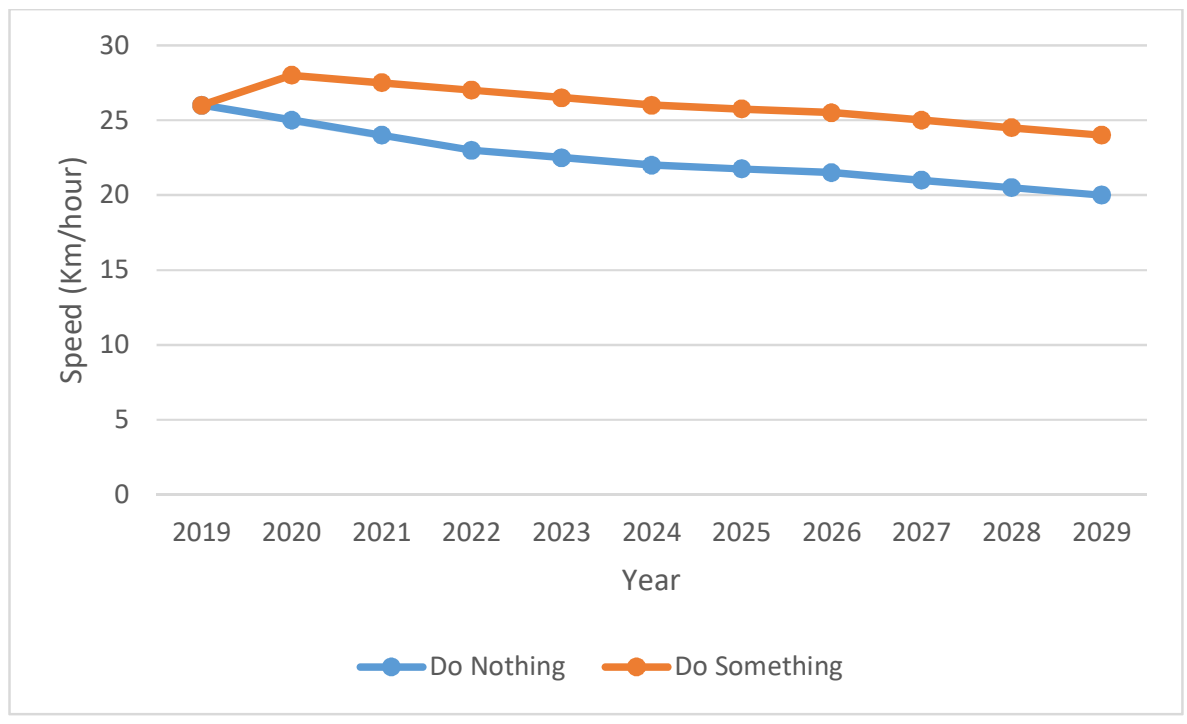

Figure 5. The Speed value changes each year for Kencong- Kasian road 


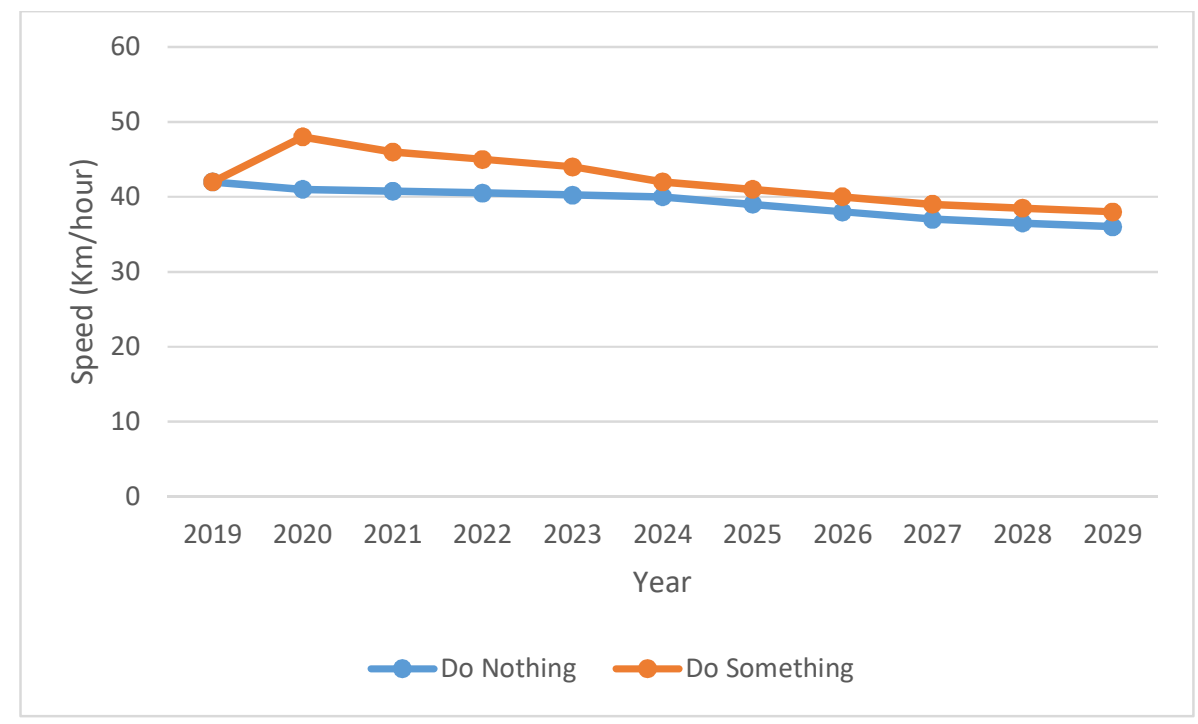

Figure 6. The Speed value changes each year for Babat - Bts. Kab. Jombang road

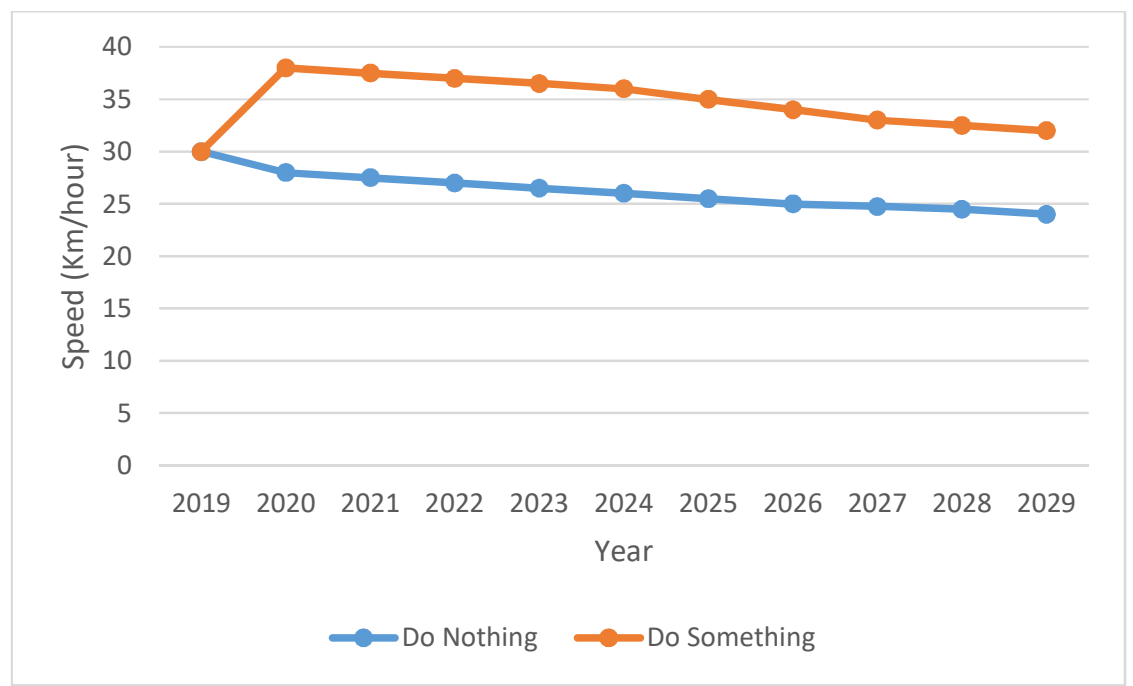

Figure 7. The Speed value changes each year for Jajag - Simpang Lima Petahunan - Pasanggaran road 


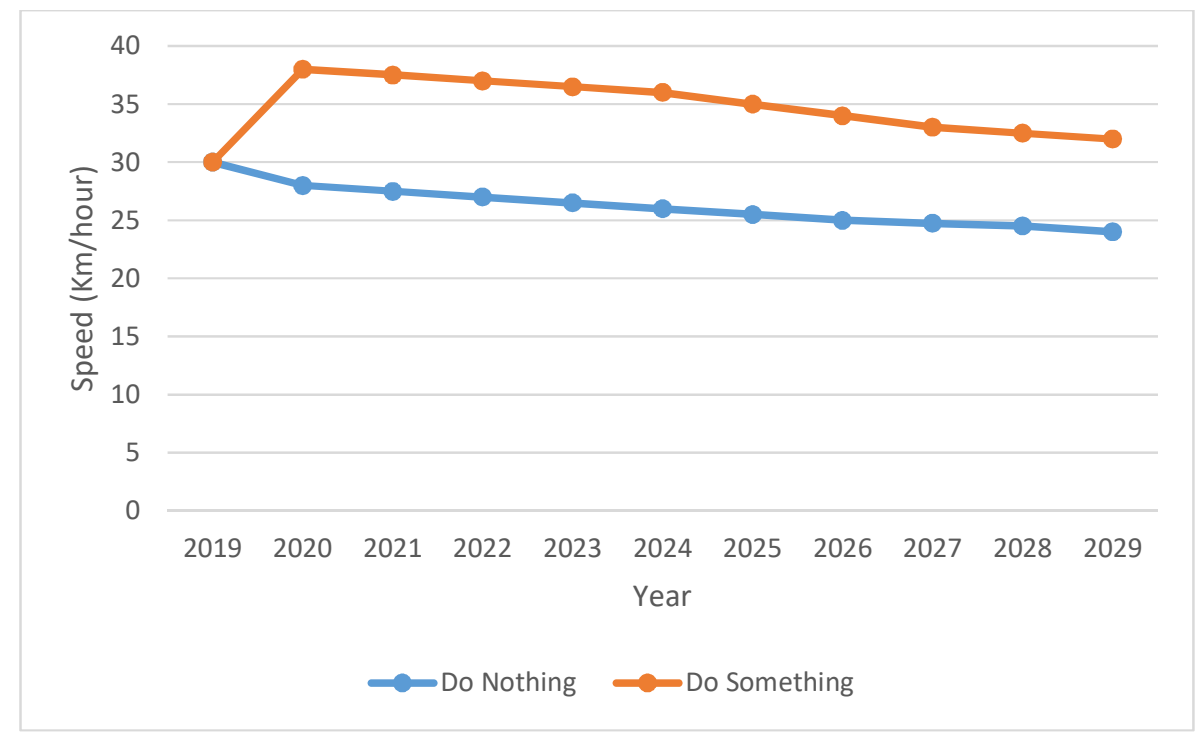

Figure 8. The Speed value changes each year for Bts. Kab. Sumenep - Pantai Lumbang road

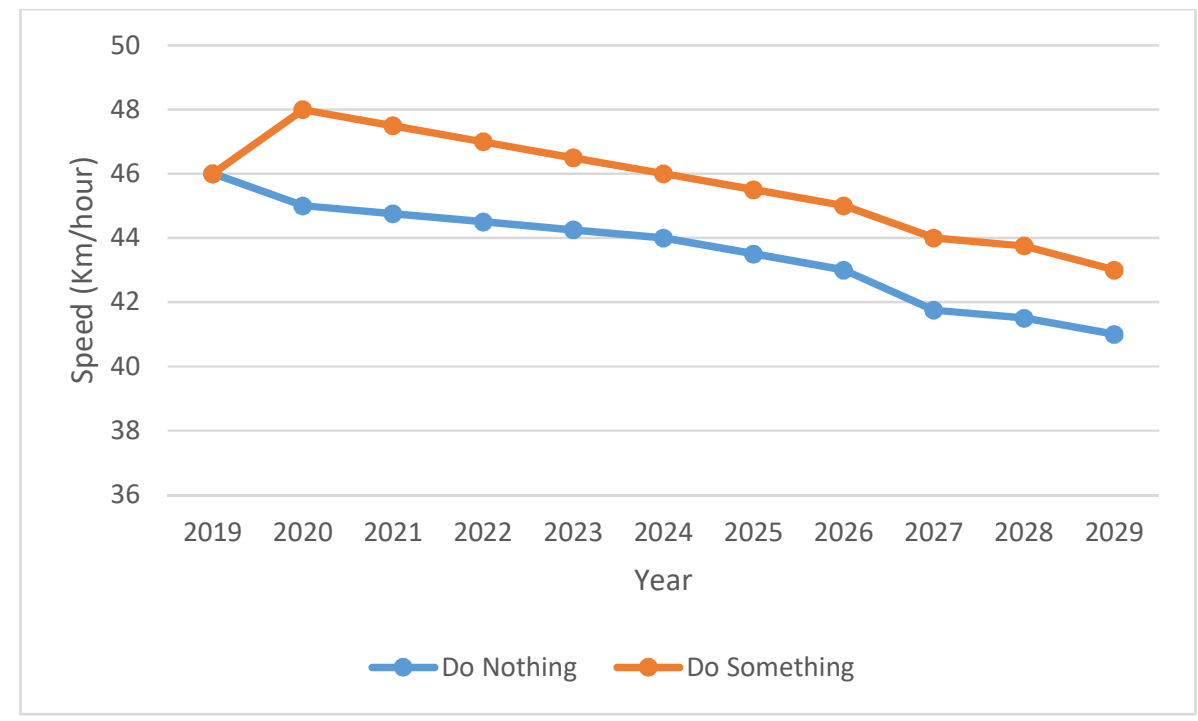

Figure 9. The Speed value changes each year for Mojokerto - Ploso road

The first-year benefit after the construction completed is counted between 2019 to 2020, it can be shown that the average change in speed experience the significant improvement for the five roads studied since the adding road capacity resulting the traffic acceleration. 
Table 7. Calculation of the Vehicle Operating Cost (VOC) saving in the first year

\begin{tabular}{lcccc}
\hline \multirow{2}{*}{\multicolumn{1}{c}{ Road Project }} & \multicolumn{2}{c}{ Year 2019 } & \multirow{2}{*}{$\begin{array}{c}\text { Saving } \\
\text { (\%) }\end{array}$} \\
\cline { 2 - 4 } & $\begin{array}{c}\text { VOC } \\
\text { Do Nothing }\end{array}$ & $\begin{array}{c}\text { VOC } \\
\text { Do Something }\end{array}$ & \\
\hline Kencong - Kasian & 8.564 .546 .323 & 8.294 .220 .611 & $3,16 \%$ \\
Babat - Bts. Kab. Jombang & 9.614 .332 .014 & 9.214 .293 .866 & $4,16 \%$ \\
$\begin{array}{l}\text { Bts. Kab. Sumenep - Pantai Lumbang } \\
\text { Jajag - Simpang Lima }\end{array}$ & 14.114 .020 .848 & 12.877 .340 .553 & $8,76 \%$ \\
$\begin{array}{l}\text { Pasanggaran } \\
\text { Bts. Kab. Mojokerto - Ploso }\end{array}$ & -8.533 .965 .400 & 7.976 .803 .851 & $6,53 \%$ \\
\hline \multicolumn{2}{l}{} & 19.146 .119 .347 & 18.822 .507 .556 & $1,69 \%$ \\
\hline
\end{tabular}

The first- year analysis shows that the road reconstruction using hardened road shoulder project gives the vehicle operating cost (VOC) saving average by $4,86 \%$.

Table 8. Calculation of the travel time saving value in the first year

\begin{tabular}{|c|c|c|c|}
\hline \multirow[b]{2}{*}{ Road Project } & \multicolumn{2}{|c|}{ Year 2019} & \multirow{2}{*}{$\begin{array}{l}\text { Saving } \\
(\%)\end{array}$} \\
\hline & $\begin{array}{c}\text { Travel Time Value } \\
\text { Do Nothing }\end{array}$ & $\begin{array}{l}\text { Travel Time Value } \\
\text { Do Something }\end{array}$ & \\
\hline Kencong - Kasian & 14.313 .723 .200 & 12.780 .110 .000 & $10,71 \%$ \\
\hline Babat - Bts. Kab. Jombang & 17.032 .845 .183 & 14.548 .888 .594 & $14,58 \%$ \\
\hline $\begin{array}{l}\text { Bts. Kab. Sumenep - Pantai } \\
\text { Lumbang } \\
\text { Jajag - Simpang L Lima }\end{array}$ & 43.495 .042 .500 & 32.048 .978 .684 & $26,32 \%$ \\
\hline Petahunan - Pasanggaran & 23.940 .190 .313 & 19.152 .152 .250 & $20,00 \%$ \\
\hline Bts. Kab. Mojokerto - Ploso & 48.608 .312 .048 & 45.570 .292 .545 & $6,25 \%$ \\
\hline & Average & & $15,57 \%$ \\
\hline
\end{tabular}

The travel time saving value in the first year after the road reconstruction using hardened shoulder project gives the saving value by $15,57 \%$. The result of the benefit from the investment spent by the East Java Province Government through the road reconstruction, periodic and routine maintenance over 10 Years investment life showed on the table below.

Table 9. The Calculation of B/C, NPV and IRR

\begin{tabular}{lccrr}
\hline \multicolumn{1}{c}{ Road Project } & Capital (Rp) & B/C & \multicolumn{1}{c}{ NPV } & \multicolumn{1}{c}{ IRR } \\
\hline Kencong - Kasian & 10.703 .112 .631 & 1,724 & 6.334 .516 .587 & $15,445 \%$ \\
Babat - Bts. Kab. Jombang & 11.254 .589 .000 & 1,039 & 360.909 .473 & $1,521 \%$ \\
Bts. Kab. Sumenep - Pantai Lumbang & 12.233 .599 .775 & 7,454 & 66.366 .575 .564 & $119,439 \%$ \\
Jajag - Simpang Lima Petahunan - & 12.674 .302 .565 & 2,690 & 18.118 .247 .794 & $37,811 \%$ \\
Pasanggaran & & & & \\
Bts. Kab. Mojokerto - Ploso & 13.748 .000 .000 & 1,369 & 4.348 .833 .699 & $9,588 \%$ \\
\hline Note: Discount Rate 12\% & & & &
\end{tabular}


The result of analysis on the table 7 can be shown that 3 (three) road segment are categorized feasible based on the economic approach since they are fulfilling the requirements B/C $>1, N P V>1$ and IRR $>r$ (discount rate), while the Babat - Bts. Kab. Jombang and Bts. Kab. Mojokerto - Ploso road are not feasible based on the economic evaluation since the value IRR $<\mathrm{r}$ (discount rate) which $12 \%$.

Table 10. The Calculation of the NPV/Capital value

\begin{tabular}{|c|c|c|c|}
\hline Road Project & $\begin{array}{c}\text { Capital } \\
\text { (Rp) }\end{array}$ & NPV & $\begin{array}{c}\text { NPV/ } \\
\text { Capital }\end{array}$ \\
\hline Kencong - Kasian & 10.703 .112 .631 & 6.334 .516 .587 & 0.591 \\
\hline Babat - Bts. Kab. Jombang & 11.254.589.000 & 360.909 .473 & 0.03 \\
\hline Bts. Kab. Sumenep - Pantai Lumbang & 12.233 .599 .775 & 66.366 .575 .564 & 5.425 \\
\hline $\begin{array}{l}\text { Jajag - Simpang Lima Petahunan } \\
\text { Pasanggaran }\end{array}$ & 12.674.302.565 & 18.118.247.794 & 1.429 \\
\hline Bts. Kab. Mojokerto - Ploso & 13.748 .000 .000 & 4.348 .833 .699 & 0.316 \\
\hline
\end{tabular}

The result of table 10 shows that the Bts. Kab. Sumenep - Pantai Lumbang road is the most feasible project followed by Jajag - Simpang Lima Petahunan - Pasanggaran road based on both the NPV and NPV/Capital value which gives a highest value among other projects.

\section{Conclusions}

The evaluation of the road reconstruction using hardened shoulder project based on the economic approach can be concluded as follows:

1. The first year benefit of the reconstruction with hardened road shoulder program gives both the vehicle operating cost (VOC) and Travel Time saving by 4,86\% and 15,57\%.

2. The 10 years benefit analysis of the reconstruction with hardened road shoulder program known that from 5 (five) roads studied only 3 (three) which feasible since fulfilling the 3 (three) main economic performance which is $\mathrm{B} / \mathrm{C}>1, \mathrm{NPV}>1$ dan Nilai IRR $>\mathrm{r}$ (discount rate $12 \%$ ) with the best rank based on the NPV/Capital respectively Bts. Kab. Sumenep - Pantai Lumbang road by 5.425, Jajag - Simpang Lima Petahunan - Pasanggaran road by 1.429 and Kencong - Kasian road 0.591 .

The suggestion which can be offer to improve the quality of the next research regarding on the benefit cost analysis of the road reconstruction using hardened shoulder program in East Java Province as follows:

1. Need to be considered the benefit of the accident cost saving

2. Need to be considered the benefit to the environmental and improvement impact on the location studied.

\section{Acknowledgements}

Special thanks to our colleagues and Supervisors of the East Java Road Province Agency, for the opportunity and the data provided for conducting the research.

\section{References}

[1] Eko S, Ridho, Ismiyati, and W. K, "Analisis Perbandingan Biaya Operasional Kendaraan (BOK) Jalan Lingkar Ambarawa dan Jalan Eksisting,” J. Karya Tek. Sipil, vol. 3, p. 10, 2014, [Online]. Available: file:///C:/Users/NoName/Downloads/6887-13040-1-SM.pdf.

[2] M. Isya and R. Anggraini, "Evaluasi Kelayakan Ekonomi Pembangunan Flyover Simpang 
Surabaya - Kota Banda Aceh,”J. Tek. Sipil, vol. 6, no. 1, pp. 93-104, 2016.

[3] D. A. Afrianti and S. Irfansyah, "Analisis Kelayakan Perencanaan Pembangunan Jalan Penghubung (Missing Link) Antara Desa Sikur Sampai Desa Paokmotong Kabupaten Lombok Timur," J. Forum Mek., vol. 7, no. 1, pp. 50-58, 2018, doi: 10.33322/forummekanika.v7i1.86.

[4] G. D. Pambudi, I. M. Suraharta, and F. Ariyani, "Analisis Kelayakan Biaya dan Manfaat Ekonomi Terhadap Rencana Pembangunan Jalan Lingkar di Kabupaten Minahasa Selatan," 18th FSTPT Int. Symp., 2015.

[5] UOB, "Notes on Road Financing," Birmingham, 2013.

[6] MnDOT, "Benefit-Cost Analysis for Transportation Projects." https://www.dot.state.mn.us/planning/program/benefitcost.html.

[7] UPJ, "Ekonomi Transportasi.” Universitas Pembangunan Jaya, South Tangerang, 2020.

[8] MKJI, "Manual Kapasitas Jalan Indonesia,” Jakarta, Indonesia, 1997.

[9] Herawati and Muchtaruddin, "Analysis of Time Value for Private and Public Transportation," War. Penelit. Perhub., vol. 25, 2013.

[10] R. Anggraini and M. Isya, "Kajian Nilai Waktu Perjalanan Untuk Mobil Penumpang ( Studi Kasus Jalan Teuku Umar Banda Aceh )," J. Tek. Sipil Univ. Syiah Kuala, vol. 1, pp. 419 430, 2017. 